\title{
THE HUNDREDTH ANNIVERSARY OF THE BIRTH OF JOSEF BENEŠ, A PROMINENT CZECH MUSEOLOGIST

\section{VÁCLAV RUTAR}

Josef Beneš was born on 1 March 1917 in Vlčnov, where he went to a primary school (1923-1928). After studies at the grammar school in Uherský Brod in 1928-1936 he attended, in the following year, the State Pedagogical Academy in Brno, and after graduation started to work as a teacher. In 1938-1955 he was first a practising teacher and then a specialist teacher in the towns of Vlčnov, Nivnice and in Uherský Brod.

In 1943 Beneš joined the ranks of voluntary museum workers in the Museum Society for Moravian Slovakia in Uherský Brod. He soon became responsible for the Ethnographic Department and later for the art collections in the Uherský Brod museum. In this period (1946-1949) he also studied art education and descriptive geometry at the Pedagogical Faculty of Palacký University in Olomouc, and employed this knowledge in his teaching activities. In 1950 he became vicechairman of the Museum Society, and after its decline chairman of a newly established museum committee temporarily in charge of the administration of the Uherský Brod museum (1951-1954). In 1955 he became its first director. In the course of his work in the museum, Beneš participated, among other thing, in the installation of an ethnographic exhibition (1947), in the preparation of an exhibition about the history of the Uherský Brod region and an exhibition dedicated to Jan Amos

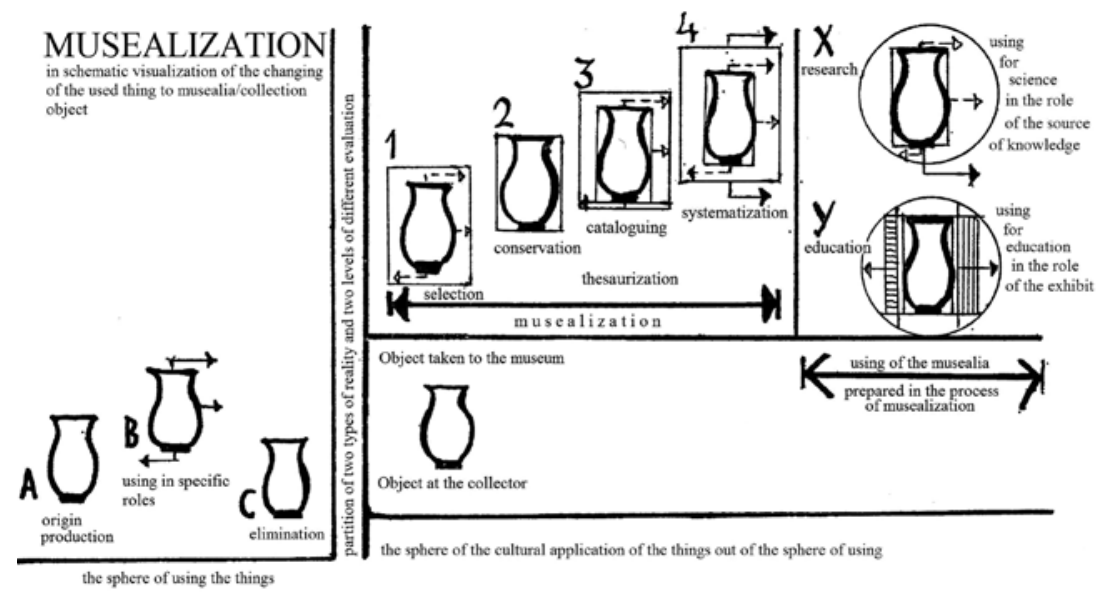

Komenský (1952, 1953). In March 1956, based on Karel Tuček's selection, he started working at the Ministry of Culture in Prague as a museum official. Even then he collaborated on the reinstallation of a permanent exhibition in the Museum of Jan Amos Komenský (1958) and prepared the concept of a similar exhibition in 1970 .

After relocating to Prague and working at the Ministry of Culture (until 1982) Josef Beneš took part in broader museum activities. In 1960-1974 he was secretary of the Central Museum Committee, in 1957-1974 held a similar position within the Czechoslovak National Committee of the ICOM. He studied ethnography at the Faculty of Arts of Charles University (1956-1961); in 1966 defended a dissertation (CSc. degree), and in 1967 became a doctor of philosophy (PhDr.). He lectured on ethnography at Prague university, and was also an external lecturer of museology at the University of J. E. Purkyně, now Masaryk university, in Brno (from 1965). In 1968-1982 he was a member of the Prague Museology Centre at the Faculty of Arts, Charles University, within the National Museum. From 1961 he was a member of the Czechoslovak Ethnographic Society at the Czechoslovak Science Academy. He wrote a large number of publications: his essential monographs were issued in the first half of the 1960s, in the late 1970s and early 1980s. Beneš summed up the results of his work in a compendium from 1997. In 1980-1992 he published within the International Committee for Museology (ICOFOM) and became its leading Czech representative (together with Jelínek, Stránský, Neustupný, Sofka). In 1990-1997 he worked as a specialist guarantor of the teaching of museology at Silesian University, Opava.

Viewing the briefly described career path of Josef Beneš, two 
major areas stand out, ethnography and museology, both of which he pursued in theory and practice, and also applied in them his extraordinary pedagogical skills.

Josef Beneš's relationship with ethnography was associated with his birthplace, Vlčnov. In 1946 he published A Year in Vlčnov 1945-1946, a series of remarkable texts and photographs (reissued in 2003), and later analysed Vlčnov folk costumes in the two-volume book Vlčnov Folk Costumes I, II (1957). Works on broader subjects include the publications Folk Art In Moravian Slovakia (1944) and Folk Art in Schools (1949). Beneš also wrote articles on ethnography for the magazines Malovaný kraj, Slovácké noviny and Brodský zpravodaj, and throughout his career published studies devoted to ethnography in specialist journals (e. g. Český lid, Múzeum, Muzejní a vlastivědná práce). He assessed and critiqued a number of ethnography exhibitions and took an interest in open-air ethnography museums. Thanks to his frequent study trips abroad (he lists 35 of them) he acquired a wealth of information about ethnography museums in different countries (Bulgaria, Romania, Poland, France, etc.) that he then presented in his specialist articles.

Beneš had close links with ethnography, which was not just reflected in written form. He was one of the founders of the Olšava folk dance group, and helped organise folk festivals in Uherský Brod, Starý Hrozenkov, Luhačovice, Javořin and Strážnice. He worked on the reconstruction of Uherský Brod folk costumes, as well as those from Vlčnov for the Vlčnovjan folk dance group. He was a honorary citizen of Vlčnov and would regularly take part in the famous local Ride of the Kings festival. ${ }^{1}$

In specialist terms, Beneš examined ethnography within the discipline of museology in the early 1960s when his first monograph on the subject was published (Development of Ethnography in the Czech Lands, 1962). Regrettably, his more museology-oriented works (Introduction to Ethnographic Museology, 1965; Issues of OpenAir Ethnography Museums, 1970; Ethnography Collections in Museums, 1984) only remained in manuscripts. Beneš in his essays most often focused on ethnography in connection with museum presentation, and his specific interest lay with folk housing and clothing.

Beneš's theme orientation was influenced by his moving to Prague. He first centred on practical work: apart from studies concerning cataloguing, registers and statistics he wrote the publication The Administration of Museum Collections (1963) that conveyed new legal standards in the field of museology. From the second half of the 1960s he published his theoretical essays, chiefly in the Muzejní a vlastivědná práce and Múzeum journals. In the latter, a Slovak periodical, he published in 1967, i.e. 50 years ago (!) his key article The Analysis of Museum Functions which he referenced in his later works. It is a contribution to general museology, which illustrates that ethnography was no longer in the centre of the author's attention. The principal part of the text is the division of the functions of the museum into four categories that are further analysed in detail. The functions are listed as follows: I. Replenishing of collections (a.

\footnotetext{
See Kings' Ride. In UNESCO Czech Heritage: Intangible UNESCO Monuments [online]. [cit. 2017 -06-15]. Available from www: <http://en.czechunesco.org/intangible-unesco-monuments/?id image $=2118>$.
}

research, b. collection of items); II. Processing of collections (a. protection of collections, b. cataloguing, c. organisation of collections); III. Scientific use of collections (a. study of collections, b. publishing of information, c. service to researchers); IV. Educational use of collections (a. exhibitions of collections, b. organisation of cultural services). All these functions are analysed and described in detail. Beneš thus in a relatively short text actually covered the major part of his approach to theoretical museology. An important part of the article is also the division of the functions as regards their importance. Educational use of collections clearly comes first, which Beneš also confirmed later in his monographs Museum and Education (1980), Cultural and Educational Activities of Museums (1981) and Museum Presentation (1981).

Presentation (and generally educational) forms at the theoretical level were also close to Beneš in relation to practical experience with museum exhibitions. He wrote articles analysing museum visitors, their division and characterization of the museum environment, and explored the use of photographs and texts. He also focused on the issues of museum brochures, invitations and catalogues and touched upon the rules of creating exhibition concepts, produced hierarchies of museum exhibits and explained the term "museum language".

Nonetheless, Beneš also addressed other museum functions even though they apparently were not of primary importance for him. In the book Museum and Collections (1977) he brought an extensive analysis of the term "collection item," discussed museum documentation and cataloguing, addressed the systematization and 
organisation of collections and the issue of depositories. The final section describes the involvement of museums in research activities and their contribution to science. In The Dictionary of Museology (1978) Beneš explains the basic museology terminology in its entirety, and despite the fact that the dictionary was only published in Czech, it remains one of the most important works in a new approach to museology.

Josef Beneš mentions the Prague museologist Jiří Neustupný as his "teacher in museology, a model and example due to his approach to museological thinking as a necessary professional skill of every museologist." Although Neustupný focused more on the scientific use of collections that on their educational function, they both agreed on the importance of special museologies, in relation to Neustupný's prehistory as well as Beneš's ethnography. Their joint activities at the Centre for the Teaching of Museology of the Faculty of Arts, Charles University within the National Museum in 1968-1981 only ended with Neustupnýs death, followed by the decline of the centre.

In the 1980s Josef Beneš took a prominent part in the activities of the newly established International Committee for Museology (ICOFOM), which provided him with a number of stimuli for his further work. He was influenced by Vinoš Sofka and Peter van Mensch. In his articles Beneš contributed to the basic issues of museum identity (published in Museological Working Papers 2, 1981), and also published in the more concretely oriented annual ICOFOM Study Series, writing on the subjects of museum substitutes (ISS 8, 1985), museum futurology (ISS 16, 1989) and museum research and its application (ISS 21, 1992).
In 1990 Josef Beneš became the specialist guarantor of the teaching of museology in Opava (until 1997). Even today, whenever the subject of Opava museology comes up, his name is always mentioned. This period saw the peak of Benešs publishing activities: the original six volumes devoted to teaching were issued in 1997 as The Basics of Museology. Prior to this Beneš addressed, in a number of brief articles listed below, museology from a non-specialist perspective, manifesting his art of viewing the discipline from a distance.

I am not familiar with Josef Beneš's short works such as Essays about Museum Matters (1993), ABCD of Museology (1995) and Museological Reading (1996). However, I have read his extraordinary Orbis Pictus Museologicus (1995), accompanied by numerous pictures manifesting the author's drawing skills (almost certainly rooted in ethnography), several times. In the opening chapter Beneš rises above the typical museological "philosophizing" when he says: "This is why I started to write about museum affairs with humour: I have written and published several hundred essays, reviews and assessments on museum studies and museology, and it was all in vain; museologists don' tread them in order to stay sane and comfortable, to avoid thinking about the essence of the subject because the most comfortable thing is not to think." I am fond of Beneš's humour with which he introduces his efforts to build a solid path for museology, spanning several decades, from a different angle. Which of them is more important, and for whom?

This year marks the 100th anniversary of the birth of PhDr. Josef Beneš, CSc. This eminent Czech museologist and ethnographer, a witty essayist and draughtsman, died on 2 October 2005, aged 88 .

\section{VÁCLAV RUTAR}

National Technical Museum, Prague, Czech Republic 